\title{
Adenosine receptors as therapeutic targets for the treatment of myocardial infarction and its complications. Part II. Post-myocardial infarction heart failure and arrhythmias*
}

\author{
Receptory adenozynowe jako cele terapeutyczne w leczeniu zawału mięśnia sercowego $i$ jego \\ powikłań. Część II. Pozawałowa niewydolność serca i zaburzenia rytmu*
}

\author{
Kamila Puchałowicz, Krzysztof Safranow, Monika Rać, Dariusz Chlubek, Violetta Dziedziejko ${ }^{\bowtie}$
}

Pomorski Uniwersytet Medyczny w Szczecinie, Katedra Biochemii i Chemii Medycznej, al. Powstańców Wlkp. 72, 70-111 Szczecin

Pomeranian Medical University in Szczecin, Department of Biochemistry and Medical Chemistry

$\triangle$ viola@pum.edu.pl

\begin{abstract}
For many years, researchers have studied the cardioprotective properties of adenosine and attempted to use the compound in the treatment of myocardial infarction. Adenosine exhibits many other effects, as well, which can be helpful in treating complications of myocardial infarction. Over the last decade, the results of over a dozen studies conducted on animal models evaluating the possibility of using adenosine receptor agonists and antagonists in the prevention and treatment of chronic heart failure and arrhythmias after myocardial infarction have been published. This is particularly important in view of the increasing number of patients suffering from such complications, associated with increased survival rates among patients due to advancements
\end{abstract}

in diagnosis and treatment of myocardial infarction itself. Current treatments for chronic heart failure and arrhythmias are mainly symptomatic and frequently are not satisfactorily effective. Cardiac remodeling, an important mechanism behind the pathogenesis of post-myocardial infarction heart failure and arrhythmias, is a promising therapeutic target.

This review presents current reports on the use of adenosine receptor agonists and antagonists as modulators of cardiac remodeling in post-myocardial infarction heart failure and arrhythmias.

Keywords: cardiac remodeling; fibrosis; inflammation; adenosine; adenosine receptors; myocardial infarction.

\begin{abstract}
ABSTRAKT
Naukowcy przez wiele lat badali kardioprotekcyjne właściwości adenozyny i próbowali wykorzystać ją w leczeniu zawału mięśnia sercowego. Zauważyli, że wykazuje ona również szereg innych właściwości, które mogą być pomocne w leczeniu powikłań zawału. W ostatnim dziesięcioleciu opublikowano wyniki kilkunastu badań prowadzonych na modelach zwierzęcych, w których oceniono możliwość zastosowania agonistów i antagonistów receptorów adenozynowych w zapobieganiu i leczeniu przewlekłej niewydolności serca i zaburzeń rytmu po zawale mięśnia sercowego. Jest to szczególne ważne ze względu na wzrastającą liczbę pacjentów cierpiących na powikłania zawału, co ma związek ze wzrostem przeżywalności
\end{abstract}

chorych wskutek ogromnego postępu w diagnostyce i leczeniu. Obecne metody leczenia przewlekłej niewydolności serca i zaburzeń jego rytmu przede wszystkim mają charakter objawowy i często są niewystarczająco skuteczne. Obiecującym celem terapeutycznym jest proces przebudowy serca, który stanowi ważny mechanizm patogenezy pozawałowej niewydolności serca i zaburzeń rytmu.

W niniejszej pracy przestawiono przegląd aktualnych doniesień na temat wykorzystania agonistów i antagonistów receptorów adenozynowych jako modulatorów procesu przebudowy serca w niewydolności serca i zaburzeniach rytmu po zawale.

Słowa kluczowe: przebudowa serca; włóknienie; zapalenie; adenozyna; receptory adenozynowe; zawał mięśnia sercowego.

\section{CHRONIC HEART FAILURE}

Chronic heart failure is a serious problem for public health due to the constantly increasing heart failure-related mortality rate, frequency of hospitalizations and expenditure on the health care system. The ageing population and the decreasing rate of heart failure patients dying due to sudden cardiac death (thanks to implantable cardioverter defibrillators) or myocardial infarction, thus leading to improved survival rates, are some of the causes of this increased prevalence. As enormous progress has been made in diagnosing and treating myocardial infarction, a considerable improvement in patient survival rates has been observed. However, this has been accompanied by an increased prevalence of infarction complications. As a result 
of ischemia-reperfusion injury, myocardium is destroyed and subsequently replaced by fibrous scar tissue, which impairs left ventricular contractility and contributes to progressing heart failure and deteriorating fitness [1]. Heart failure is the main cause of late mortality after successful revascularization and poses a considerable challenge to contemporary cardiology. For this reason, prevention of post-myocardial infarction heart failure is a major therapeutic objective nowadays [2].

The contemporary methods for treating heart failure with reduced left ventricular ejection fraction focus on preventing adaptive neurohormonal activity and decreasing cardiac afterload by lowering arterial blood pressure and heart rate. However, there is a need for a wider range of therapeutic methods that will not only modulate hemodynamic parameters but also affect the pathological processes taking place within the myocardium [3]. Nevertheless, the complexity and diversity of the mechanisms involved in the pathogenesis of heart failure in individual patients, which include i.a. microcirculatory dysfunction, inflammation and remodeling, may be the cause of diverse responses to treatment [4]. One important area of research is cardiac remodeling. This phenomenon results from dynamic cellular and molecular processes that lead to permanent changes in the geometry and function of the ventricles after myocardial infarction or secondary to chronic arterial hypertension [5]. Remodeling is driven by mechanical (cardiomyocyte stretching) and neurohormonal factors. Activation of the sympathetic nervous system and the renin - angiotensin - aldosterone system (RAAS) constitutes a compensatory mechanism designed to preserve the ejection fraction [6]. It has been shown that as a result of $\alpha 1$-adrenergic receptor activation, hypertrophic and fibrotic processes, as well as oxidative stress, are stimulated [7]. As for myocardial hypertrophy, it is the major determinant of mortality in heart failure patients [8]. Currently, prevention and treatment of left ventricular remodeling are achieved by using $\beta$-blockers, ACE inhibitors and aldosterone antagonists and by providing cardiac rehabilitation. The overall effectiveness of these methods in relation to the prevalence of cardiovascular diseases and the related mortality is unsatisfactory [5].

\section{ADENOSINE RECEPTOR AGONISTS IN POST-MYOCARDIAL HEART FAILURE TREATMENT}

Adenosine receptors are among the new pharmacological targets in the treatment of chronic heart failure. Released by cardiomyocytes in response to hypertrophic factors, adenosine participates in activating adaptative mechanisms intended to restrict the size of the hypertrophic region. This is accompanied by increased $A_{1}$ receptor expression in response to the stimulation of $\alpha 1$-adrenergic receptors [7]. Adenosine protects cardiomyocytes from excessive exposure to catecholamines, weakens RAAS activation and reduces endothelin-1 production. Based on animal model studies, it has been shown that activating the $A_{1}$ receptor [9] or blocking the $A_{3}$ receptor may prevent cardiomyocyte hypertrophy, myocardial dysfunction and the development of heart failure caused by pressure overload of the heart. The beneficial effects of $\mathrm{A}_{3}$ receptor blocking have been explained by Lu et al. [10] in their study performed on a murine transverse aortic constriction (TAC) model, where myocardial hypertrophy and heart failure were induced by transverse coarctation of the aorta. Their results indicate that the $\mathrm{A}_{3}$ receptor participates in the pathogenesis of cardiac remodeling, oxidative stress and inflammation by activating the mitogen-activated protein kinase (MAPK) and phosphatidylinositol 3-kinase/protein kinase B (PI3K-Akt) pathways but does not affect the structure and function of the left ventricle in the normal heart.

To date, several papers have been published that aimed to assess the utility of agonists of select adenosine receptors in preventing and treating post-myocardial infarction heart failure. Substantial attention has been paid to utilizing partial adenosine $A_{1}$ receptor agonists. They are a promising group of compounds due to their potential lack of effect on hemodynamic parameters, their ability to improve cardiomyocyte energy metabolism and $\mathrm{Ca}^{2+}$ homeostasis, and their beneficial impact on the structure and function of the myocardium [3]. The results of pre-clinical studies indicate that, contrary to full agonists, partial adenosine $A_{1}$ receptor agonists protect and improve cardiac function without causing adverse cardiac or non-cardiac effects, e.g. bradycardia, atrioventricular block or antidiuretic activity [11,12]. One example of a partial agonist is capadenoson (BAY 68-4986), which has thus far been assessed in clinical studies of atrial fibrillation and stable angina pectoris [13]. It is characterized by high specificity and affinity for the $\mathrm{A}_{1}$ receptor and favorable pharmacokinetic properties. Its chronic oral administration has been shown to improve left ventricular function and prevent remodeling in dogs with heart failure. The benefits of using capadenoson result from its ability to protect the weakened myocardium against the effects of factors exacerbating cellular damage and death, to deliver the energy required for the myocardium to work (restoration of normal expression of glucose transporters GLUT-1 and GLUT- 4 and the mCPT-1 protein that controls $\beta$-oxidation) and to restrict fibrosis [11]. At present, phase II clinical trials using another partial adenosine $A_{1}$ receptor agonist, neladenoson bialanate (BAY 1067197), in patients with chronic heart failure with reduced left ventricular ejection fraction (PANTHEON), are being carried out. So far, it has been shown that this compound is safe and causes no impairments in atrioventricular conduction or neurological side effects $[14,15]$. Another promising agent is the $\mathrm{A}_{2 \mathrm{~A}}$ receptor agonist LASSBio-294. Its oral administration to spontaneously hypertensive rats (SHR) after myocardial infarction prevents the development of cardiac dysfunction and improves exercise tolerance. This is particularly important, as exercise tolerance largely determines quality of life of heart failure patients [5]. Improved exercise tolerance results from this compound's effect on hemodynamic parameters [5] and skeletal muscle contractility (it restores calcium homeostasis) [16]. Evidence has been presented that LASSBio-294 prevents cardiac remodeling - reducing collagen deposition in the myocardium and thus limiting fibrosis, 
inhibits the inflammatory response and contributes to preserving normal thickness of the anterior wall of the left ventricle. Moreover, it has a positive inotropic effect and demonstrates hypotensive activity [5]. These properties of adenosine receptor agonists indicate their potential for use in the treatment of heart failure after myocardial infarction. Nonetheless, this area has not yet been well-explored, and there is a need for more pre-clinical studies and large randomized clinical trials on selective $A_{1}$ and $A_{2 A}$ receptor agonists.

\section{POST-MYOCARDIAL INFARCTION ARRHYTHMIAS}

During the myocardial infarction event and in the period that follows, serious metabolic and electrophysiological changes occur which initiate the development of potentially lethal arrhythmias. Common are ventricular tachyarrhythmias (ventricular tachycardia, ventricular fibrillation), which are frequently the cause of sudden cardiac death. Their etiopathogenesis varies depending on the time from symptom onset. Tachyarrhythmias occurring in the acute phase of myocardial infarction, until as late as 48-72 h after symptom onset, are the result of reversable changes within the myocardium. Such changes include acidosis, changes in the function of the cell membrane ( $\mathrm{K}^{+}$outflow and $\mathrm{Ca}^{2+}$ influx) and a reduction in resting potentials, which contribute to electrical instability. Within a period between $72 \mathrm{~h}$ and several weeks or months after the infarction, arrhythmias are triggered by changes to the electrical conduction system of the heart that result from cardiac remodeling $[17,18]$. During that time, the function of ion channels (inactivation of sodium channels, changes in the activity of calcium and potassium channels and the sodium-calcium exchanger) and intercellular junctions change, and collagen content in the myocardium rises [19]. These changes are caused by irregularities in the infarcted myocardium repair processes that follow 3 phases: the inflammatory phase, the proliferative phase and the maturation phase. Excessive production and release of proinflammatory cytokines (TNF- $\alpha$, IL-1 $\beta$, IL-6) and proteases (matrix metalloproteinases), as well as the exacerbation of fibrosis, are the major mechanisms responsible for dangerous post-infarction ventricular arrhythmias. The anti-arrhythmic drugs used nowadays, such as $\beta$-blockers and ACE inhibitors, prevent arrhythmias by affecting the neurohormonal system; it is symptomatic treatment. They do not, however, treat the cause of arrhythmias - the electrophysiological and structural remodeling of the heart. Redirecting attention to the inflammatory or proliferative phase is a promising therapeutic strategy in the treatment of post-infarction cardiac arrhythmias [20].

\section{ADENOSINE IN ARRHYTHMIA THERAPY}

Adenosine is an endogenous compound with a confirmed antiarrhythmic effect and has been used in clinical practice for over 6 decades. Recurrent supraventricular tachycardia is the main indication for adenosine therapy, but it can also be effective in treating other forms of supraventricular and ventricular arrhythmias, e.g. sinus node reentrant tachycardia triggered atrial tachycardia, atrioventricular nodal reentrant tachycardia and ventricular tachycardia due to cyclic adenosine monophosphate-mediated (cAMP) triggered activity. Moreover, it is used in differential diagnosis of supraventricular tachycardia [21]. The antiarrhythmic effect of adenosine results from activation of the $\mathrm{G}_{\mathrm{i} / \mathrm{o}}$-coupled adenosine $\mathrm{A}_{1}$ receptor in the sinoatrial node and ventricular myocardium. In supraventricular tissue, this leads to the activation of inward-rectifier potassium channels, and subsequently to hyperpolarization of sinoatrial node cells (negative chronotropic effect) and slowing down of conduction in the sinoatrial node (negative dromotropic effect). Adenosine has an inhibitory effect on the sinoatrial node by restricting the activity of adenylate cyclase (AC) and lowering cAMP concentration. This effect is particularly visible with prior AC stimulation by catecholamines. A strong negative dromotropic effect is desirable in the treatment of supraventricular tachyarrhythmias resulting from an acute reversible stress, e.g. myocardial infarction, sepsis or thoracic surgeries. Adenosine does not exert a direct influence on the resting and action potential in the ventricular myocardium, or its influence is unremarkable due to the lack of rectifier potassium channels. By inhibiting the activity of AC, it prevents the stimulating effect of cAMP on the inward calcium current, and on other ion channels dependent on $\beta$-adrenergic receptor activation. However, adenosine may also, through the $\mathrm{A}_{1}$ receptor, exert a proarrhythmic effect (bradyarrhythmia, atrial fibrillation), and cause transient sinus arrest or bifascicular block [21, 22]. The side effects of adenosine administration include, inter alia, flushing, dyspnea or a sense of discomfort in the chest, which are caused by activation of the remaining adenosine receptors. Therefore, more and more selective $A_{1}$ receptor agonists are being introduced whose antiarrhythmic effect is devoid of such adverse effects. Among them are tecadenoson, selodenoson and trabodenoson [21].

\section{ADENOSINE RECEPTOR AGONISTS AND ANTAGONISTS IN POST-MYOCARDIAL INFARCTION ARRHYTHMIA TREATMENT}

Late post-myocardial infarction ventricular arrhythmias require long-term therapy due to their association with an increased risk of sudden cardiac death. Patients with left ventricle damage and reduced ejection fraction are especially at risk of developing such arrhythmias. Therefore, prevention of cardiac remodeling may protect them from developing not only chronic heart failure but also arrhythmia. Due to the high complexity of the pathomechanisms of late post-infarction arrhythmias, many are therapeutic targets for adenosine receptor modulators. From a therapeutic point of view, fibrosis is an essential outcome of cardiac remodeling, because if uncontrolled it will act as a trigger and propagator of reentrant arrhythmias, including ventricular tachycardia [23]. 
Reducing fibrosis decreases susceptibility to arrhythmias and the risk of sudden cardiac death [19]. In vitro studies on cardiac fibroblasts show that adenosine prevents fibrotic processes in the heart, acting through the $\mathrm{A}_{2 \mathrm{~B}}$ receptor [24]. It has been demonstrated on a murine model that chronic administration of the stable adenosine analogue 2-chloroadenosine (CADO) one week after myocardial infarction prevents remodeling processes, including fibrosis, and improves cardiac function. This effect is dependent on the $A_{2 B}$ receptor only [25]. Contrary to the aforementioned results, however, there are reports based on in vivo animal models that point to the stimulation of fibrosis through the $\mathrm{A}_{2 \mathrm{~B}}$ receptor and to the possibility of achieving clinical benefits by blocking it [24], e.g. reduction of cardiac remodeling [26]. The $A_{2 B}$ adenosine receptor antagonist GS-6201 improves cardiac function and prevents ventricular arrhythmia in post-myocardial infarction rats. This effect results from inhibiting fibrosis in the borderline zone by reducing TGF- $\beta$ production and inhibiting fibroblast transformation and collagen production, which contributes to a higher homogeneity of the myocardium. As a consequence, the pace of conduction in the borderline zone and the infarction area is accelerated, and the risk of ventricular tachycardia decreases. These positive effects have been observed only when treatment is commenced one week after myocardial infarction, but not when it is commenced the following day. Early application of GS-6201 has an adverse effect on the process of post-infarction wound healing - by inhibiting fibrosis it hinders the preservation of myocardial structural integrity and, therefore, contributes to worse cardiac function. In turn, inhibition of fibrosis after the acute post-infarction wound has healed prevents the occurrence of remodeling and its adverse consequences [23]. It is unclear why one receptor subtype can act as an intermediary in both pro- and antifibrotic activity. It is suspected that the type and duration of the cardiac incident are decisive factors. Activation of adenosine receptors in acute ischemia is more likely to prevent fibrosis, while its profibrotic effect occurs under chronic myocardial stress conditions. This claim is supported by the results of studies assessing fibrotic processes in the kidneys and lungs. Further research is required to elucidate the exact mechanism responsible for such opposing effects, but the activation of signaling pathways related to different G proteins is one possibility. The $\mathrm{A}_{2 \mathrm{~B}}$ receptor is characterized by an ability to couple with many $G$ proteins and diverse signaling pathways, depending on the condition of the cells and the stage of the disease. It has been found that activation of the $\mathrm{G}_{\mathrm{s}}$ protein-dependent pathway is responsible for inhibiting profibrotic gene expression, and activation of the $\mathrm{G}_{\mathrm{q}}$ protein-dependent pathway favors such expression [24]. At present, only a small number of papers have assessed the utility and mechanisms behind the activity of adenosine receptor agonists and antagonists in post-myocardial infarction arrhythmia prevention and treatment based on inhibiting the electrophysiological and structural remodeling of the heart. However, these processes constitute a promising therapeutic target, which is why further research in this field is warranted.

\section{SUMMARY AND DIRECTIONS FOR FUTURE RESEARCH}

Research on cardiac remodeling, with a focus on fibrosis, is becoming increasingly popular. Limiting cardiac remodeling is an important therapeutic objective due to its association with the prevalence and progression of such complications of myocardial infarction as chronic heart failure and arrhythmias. The results of pre-clinical studies conducted thus far indicate that agonists of select adenosine receptors protect the heart from the activity of hypertrophic compounds, improve cardiomyocyte energy metabolism and inhibit myocardial fibrosis, thereby contributing to improved cardiac function and helping to develop better exercise tolerance. Additionally, $\mathrm{A}_{2 \mathrm{~A}}$ receptor antagonists have been reported to exert a potential antiarrhythmic effect thanks to their ability to inhibit fibrosis, which favors greater homogeneity of the myocardium. However, the conclusions drawn to date are based only on the outcomes of research performed on experimental animal models. Therefore, further research must be conducted that will lead to multi-center randomized clinical trials on humans and allow for a full utilization of the potential of adenosine receptor modulators.

\section{REFERENCES}

1. Ibáñez B, Heusch G, Ovize M, Van de Werf F. Evolving therapies for myocardial ischemia/reperfusion injury. J Am Coll Cardiol 2015;65(14):1454-71.

2. Cahill TJ, Kharbanda RK. Heart failure after myocardial infarction in the era of primary percutaneous coronary intervention: Mechanisms, incidence and identification of patients at risk. World J Cardiol 2017;9(5):407-15.

3. Greene SJ, Sabbah HN, Butler J, Voors AA, Albrecht-Küpper BE, Düngen HD, et al. Partial adenosine $A_{1}$ receptor agonism: a potential new therapeutic strategy for heart failure. Heart Fail Rev 2016;21(1):95-102.

4. Heusch G, Gersh BJ. The pathophysiology of acute myocardial infarction and strategies of protection beyond reperfusion: a continual challenge. Eur Heart J 2017;38(11):774-84.

5. Da Silva JS, Gabriel-Costa D, Sudo RT, Wang H, Groban L, Ferraz EB, et al. Adenosine $\mathrm{A}_{2} \mathrm{~A}$ receptor agonist prevents cardiac remodeling and dysfunction in spontaneously hypertensive male rats after myocardial infarction. Drug Des Devel Ther 2017;11:553-62.

6. Jackson G, Gibbs CR, Davies MK, Lip GY. ABC of heart failure. Pathophysiology. BMJ 2000;320(7228):167-70.

7. Puhl SL, Kazakov A, Müller A, Fries P, Wagner DR, Böhm M, et al. Adenosine $A_{1}$ receptor activation attenuates cardiac hypertrophy and fibrosis in response to $\alpha 1$-adrenoceptor stimulation in vivo. Br J Pharmacol 2016;173(1):88-102.

8. Pang T, Gan XT, Freeman DJ, Cook MA, Karmazyn M. Compensatory upregulation of the adenosine system following phenylephrine-induced hypertrophy in cultured rat ventricular myocytes. Am J Physiol Heart Circ Physiol 2010;298(2):H545-53.

9. Liao Y, Takashima S, Asano Y, Asakura M, Ogai A, Shintani Y, et al. Activation of adenosine $A_{1}$ receptor attenuates cardiac hypertrophy and prevents heart failure in murine left ventricular pressure-overload model. Circ Res 2003;93(8):759-66.

10. Lu Z, Fassett J, Xu X, Hu X, Zhu G, French J, et al. Adenosine $A_{3}$ receptor deficiency exerts unanticipated protective effects on the pressure-overloaded left ventricle. Circulation 2008;118(17):1713-21.

11. Sabbah HN, Gupta RC, Kohli S, Wang M, Rastogi S, Zhang K, et al. Chronic therapy with a partial adenosine $\mathrm{A}_{1}$-receptor agonist improves left ventricular function and remodeling in dogs with advanced heart failure. Circ Heart Fail 2013;6(3):563-71. 
12. Dinh W, Albrecht-Küpper B, Gheorghiade M, Voors AA, van der Laan M, Sabbah HN. Partial adenosine $\mathrm{A}_{1}$ agonist in heart failure. Handb Exp Pharmacol 2017;243:177-203.

13. Baltos JA, Vecchio EA, Harris MA, Qin CX, Ritchie RH, Christopoulos A, et al. Capadenoson, a clinically trialed partial adenosine $\mathrm{A}_{1}$ receptor agonist, can stimulate adenosine $A_{2 B}$ receptor biased agonism. Biochem Pharmacol 2017;135:79-89.

14. Meibom D, Albrecht-Küpper B, Diedrichs N, Hübsch W, Kast R, Krämer T, et al. Neladenoson bialanate hydrochloride: a prodrug of a partial adenosine $A_{1}$ receptor agonist for the chronic treatment of heart diseases. ChemMedChem 2017;12(10):728-37.

15. Voors AA, Düngen HD, Senni M, Nodari S, Agostoni P, Ponikowski P, et al. Safety and tolerability of neladenoson bialanate, a novel oral partial adenosine $A_{1}$ receptor agonist, in patients with chronic heart failure. J Clin Pharmacol 2017;57(4):440-51.

16. Da Silva JS, Pereira SL, Maia Rdo C, Landgraf SS, Caruso-Neves C, Kümmerle AE, et al. $\mathrm{N}$-acylhydrazone improves exercise intolerance in rats submitted to myocardial infarction by the recovery of calcium homeostasis in skeletal muscle. Life Sci 2014;94(1):30-6.

17. Gorenek B, Blomström Lundqvist C, Brugada Terradellas J, Camm AJ, Hindricks $\mathrm{G}$, Huber $\mathrm{K}$, et al. Cardiac arrhythmias in acute coronary syndromes: position paper from the joint EHRA, ACCA, and EAPCI task force. Europace 2014;16(11):1655-73.

18. Bhar-Amato J, Davies W, Agarwal S. Ventricular arrhythmia after acute myocardial infarction: 'The perfect storm'. Arrhythm Electrophysiol Rev 2017;6(3):134-9.
19. Azevedo PS, Polegato BF, Minicucci MF, Paiva SA, Zornoff LA. Cardiac remodeling: concepts, clinical impact, pathophysiological mechanisms and pharmacologic treatment. Arq Bras Cardiol 2016;106(1):62-9.

20. Francis Stuart SD, De Jesus NM, Lindsey ML, Ripplinger CM. The crossroads of inflammation, fibrosis, and arrhythmia following myocardial infarction. J Mol Cell Cardiol 2016;91:114-212.

21. Szentmiklosi AJ, Galajda Z, Cseppento Á, Gesztelyi R, Susán Z, Hegyi B, et al. The Janus face of adenosine: antiarrhythmic and proarrhythmic actions. Curr Pharm Des 2015;21(8):965-76.

22. Lerman BB. Ventricular tachycardia: mechanistic insights derived from adenosine. Circ Arrhythm Electrophysiol 2015;8(2):483-91.

23. Zhang $\mathrm{H}$, Zhong H, Everett TH 4th, Wilson E, Chang R, Zeng D, et al. Blockade of $\mathrm{A}_{2 \mathrm{~B}}$ adenosine receptor reduces left ventricular dysfunction and ventricular arrhythmias 1 week after myocardial infarction in the rat model. Heart Rhythm 2014;11(1):101-9.

24. Vecchio EA, White PJ, May LT. Targeting adenosine receptors for the treatment of cardiac fibrosis. Front Pharmacol 2017;8:243.

25. Wakeno M, Minamino T, Seguchi O, Okazaki H, Tsukamoto O, Okada K, et al. Long-term stimulation of adenosine $\mathrm{A}_{2 \mathrm{~B}}$ receptors begun after myocardial infarction prevents cardiac remodeling in rats. Circulation 2006;114(18):1923-32.

26. Toldo S, Zhong H, Mezzaroma E, Van Tassell BW, Kannan H, Zeng D, et al. GS-6201, a selective blocker of the $A_{2 B}$ adenosine receptor, attenuates cardiac remodeling after acute myocardial infarction in the mouse. J Pharmacol Exp Ther 2012;343(3):587-95. 